\title{
Identity and Security in Arab Countries
}

\section{Mustapha Kamal Al-Sayyid}

\begin{abstract}
This article takes a critical stand towards primordialist interpretations of identity conflicts in the Arab world. It argues that identity-framed conflicts have usually coincided with differential access to wealth, power or status of the groups in conflict. This has been the case in the bloodiest inter-group conflicts in Arab countries, namely those in Sudan, Iraq and Lebanon. It also argues that political divisions based on ideology or religion have often been more important than ethnic or racial differences - as in the Algerian civil war, the recent confrontation between government and opposition supporters and conflict between FATAH and HAMAS in Palestine. These conflicts had important implications for human, as well as national, regional and international security.
\end{abstract}

This article argues that the time has come to examine security implications of identity conflicts not in terms of conventional security analysis that deals with the 'physical' dimension of violent conflict, but more particularly its human security dimension, i.e. the extent to which these conflicts affect people's freedom from want and fear and their need for respect. Recognition of and respect for different cultural, religious and ethnic identities is an aspect of human security.

In countries like Sudan, Lebanon, Iraq, Palestine and Algeria, violent conflicts have led to the loss of hundreds of thousands of lives. They have also affected other dimensions of human security such as levels of unemployment, poverty, health and personal security. In Sudan, Iraq, Algeria and the Palestinian Territories, levels of unemployment have run close to one-quarter of the whole population, with standards of living falling dramatically. Those most victimised by these conflicts were expectedly those living in combat zones in Southern Sudan and Darfur, in the Kurdish region in Iraq and the poor communities in Lebanon and Palestinians of Gaza, who were subjected to the brutal Israeli military onslaught which began on 26 December 2008 (UNDP 2009, forthcoming).

But in what senses have these and other conflicts in the Arab region been identity conflicts? And is there a germ of violent conflict in all situations involving differences of identity? The obvious answer to the latter is that this is not always the case. While identity differences have given rise to inter-group tensions and conflicts in some countries, in other countries groups claiming different identities have coexisted peacefully over long periods of time. Nevertheless, conflicts apparently rooted in differences of identity have continued to draw the attention of scholars and the general public in the Arab world.

\section{Multiple markers of identity and how they frame conflicts in the Arab world}

Those who argue that conflicts are rooted in primordial loyalties, based on the latent solidarities within ethnic groups contend that when disputes arise, members of concerned groups unthinkingly take the side of their fellows from the same identity group against the 'others'. They react under the impulse of what they sense to be bonds of kinship amounting almost to blood ties with those of their group (Connor 1994).

This short article argues against this kind of reasoning as applied to the Arab world, on several grounds. To start with, there are numerous types of identity in the Arab world. Some are based on primordial loyalties inherited at birth (Geertz 1994), but others are ignited by ideological or 
political differences. Scholars interested in ethnic conflict classify the dividing lines among people living in the Arab world in a number of ways, including religion, language and race. They acknowledge three major religions (i.e. Islam, Christianity and Judaism), with a smaller number of animists mostly in Sudan. Linguistically, while Arabic is spoken by the majority in the Arab world, there are important minorities speaking other languages, such as Kurdish in Iraq and Syria, Berber in North African countries and a variety of African languages in Sudan.

Additionally, some identities are rooted in sectarian or community ties, such as those of Sunnis and Shi'is as well as those of the Druze and Alawites, who all claim to be Muslims. Similar sectarian divisions are found among Christian Arabs who belong to denominations, such as Copts, Greek Orthodox, Catholics and Protestants, to name the largest. In some cases, people could share the same religion and communal origin, but differ in terms of their tribal descent. This is the case in Gulf countries, Yemen and Somalia (Ibrahim 1998: 229-42).

Yet primordial loyalties are by no means the only identity markers. Just as important are markers of political identity, the most important expression of which concerns membership of political movements. Thus, there exist Arab Nationalists, Marxists, Nasserites, Liberals and Islamists. The latter in particular have become the dominant opposition group in most Arab countries.

Furthermore, primordialist interpretations of conflict gloss over divisions within the same identity group. As evident, for example, in Iraq, competing factions within the same ethnic group fought and continue to fight with one another. The Shi'i followers of Muqtada Al-Sadr have raised arms against other Shi'i militias. The two Kurdish parties in Northern Iraq were involved in heavy fighting with each other in 1994 and 1996, which was halted only after lengthy mediation efforts by US officials (Ghareeb 2003: 180). The last episodes of the Lebanese civil war were marked by fierce fighting opposing Christian factions (Corm 2005: 408-16). The last confrontation, in 2006-8, between the Loyalists and the Opposition in Lebanon placed both Christians and Sunnis in opposing camps.

Another argument against primordialist interpretations of identity-framed conflicts is that multiplicity of identities for any individual is usually the rule. Identities tend to be socially constructed according to context. Members of a group sharing certain objective traits, like a common religion, language or territorial origin most likely have other traits that they share with other groups. Which of these identities prevails in any situation depends on the circumstances. Conflict situations are characterised by significant manipulation of such identity markers, a phenomenon to which writers, poets, novelists, singers and political activists contribute. The former often stress the common heritage of their own group, while the latter diffuse the image of a polarised society divided into a dominant group and a persecuted one in order to augment their political capital.

In other Arab countries, political violence has arisen for reasons having little or nothing to do with ethnic and other divisions. The bloodiest instance was the civil war in Algeria, which began in 1992 and lasted for almost a decade. Domestic violence on a lower scale also erupted in other Arab countries, including Syria in the late 1970s and early 1980s; Egypt in the 1980s until 1997; Saudi Arabia since 1979 and Yemen since 2001. While the antagonists in these cases have included young Islamists on one side and government forces and secularist intellectuals on the other side, it would be misleading to associate Islam per se with armed opposition to the government. In fact, the militant Islamists who took up arms usually constituted a small fraction of the Islamist movement. ${ }^{1}$ The broadest part of this movement is made up of people who abide very much by the rules of a peaceful political game. The greatest successes of the Islamist movement have been registered by those who have sought to reach power through elections.

If it is not true that mere differences of identity necessarily give rise to inter-group tension and conflicts, why does it seem that groups claiming different identities find themselves divided into hostile camps in the Arab world, as in other parts of the world? And what are the security implications of such conflicts of identity?

\section{Identity politics and national security}

Identity politics plays out in many different ways, not all of them leading to the eruption of conflict (Luckham et al. 2006: 4-9), as demonstrated in several Arab countries where differences of 
identity, primordial or political, did not lead either to open tension or violent conflict. Morocco, Tunisia and Jordan since 1970 are such examples.

There are Amazigh populations in Morocco and Tunisia and Christians and Circassians in Jordan, but all three countries have been more or less free of ethnic conflict since their independence. In Morocco in particular as Geertz (1994) has observed, primordial divisions between Arabs and Amazighs did not produce differentiated political identities or conflicts between them - in contrast to Indonesia, where primordial loyalties gave rise to several bloody conflicts. What prevailed there was more a multitude of personal loyalties closer to the patron-client relationships as described in detail by Gellner and Waterbury (1977).

One might object to Jordan's inclusion in this grouping, arguing that the so-called Black September episode in 1970 indicated ethnic conflict since the antagonists were Palestinian combatants and the Jordanian army. Some Jordanians also feel that Palestinians who have acquired Jordanian nationality exert too much control over the economy and represent a large portion of the country's intelligentsia. However, such feelings have not produced protracted conflict. The 1970 confrontation did not pit Palestinians against Jordanians but particular armed Palestinian groups against the security forces of the Jordanian government which, encouraged by the USA, did not want these armed groups to become a state within the state.

Syria occupies a unique place as it seems presently to be largely free of ethnic tensions, despite skirmishes between the government forces and the Kurdish population on several occasions since 2003. Several observers would find an ethnic element in the confrontation between members of the Muslim Brotherhood and the Syrian government, particularly in the late 1970s and early 1980s. The Muslim Brotherhood perceived the Ba'ath government to be dominated by Alawis, whom they do not consider Muslims. The assault on the Military Academy of Hama in 1982 targeted military cadets who were mostly Alawis. The Syrian Army bombarded Hama, a predominantly Sunni city for several days. Victims of the bombardment, estimated to have been close to 10,000, were mostly Sunnis (Seale 1988). But this brutal reprisal by the Syrian regime put an end to armed revolt by members of the Muslim Brotherhood.

Some other countries have known certain tensions among people with diverse religious or communal backgrounds that did not escalate into full-scale civil war. In Egypt, for example, episodic violence has been breaking out between Muslims and Copts since the 1970s, including attacks on Coptic churches. Complaints of offences against religion were aired in protest marches organised by Muslims and Copts alike, each attributing responsibility for these offences to those belonging to the other religion. The violence triggered on these occasions was usually contained, thanks to intervention by local leaders.

Inter-group tension led to massive protest demonstrations in Bahrain as well, but it abated with the adoption of a national charter in 2001 that promised to turn Bahrain into a constitutional monarchy. The proclamation of the charter was followed by the organisation of legislative elections and the formation of the Shura-Consultative Assembly, which included representatives from the two major

communities, namely Sunnis and Shi'is, although the latter felt that their numerical majority in the country was not reflected in the composition of this assembly. Newspapers also reported manifestations by Shi'i intellectuals in the eastern part of Saudi Arabia in the last few years (Al-Rasheed 1998: 121-38). Certain conciliatory measures were taken by King Abdallah upon accession to the throne. Increased (even if limited) freedom of expression, as well as the general prosperity in the country thanks to high oil prices have contributed to lessening Shi'i discontent (Al-Rasheed 2007).

Differences of political identity, on the other hand, have seriously threatened national security in other Arab countries. The most important of these political identities were those rooted in interpretations of Islam as well as opposed political affiliations in the cases of Occupied Palestinian Territories and Lebanon. Islamist militants, who believe that political systems in Arab countries should be based on their own interpretations of the principles of Islamic Shari'a, were involved in armed clashes with their governments. They also targeted those whom they perceived to be secularist 
intellectuals. This confrontation brought a decade-long civil war to Algeria, resulting in the death of more than 100,000 people. Egypt, Yemen and Saudi Arabia too have experienced such clashes, although on a smaller scale. In fact, such confrontations were echoed in most Arab countries either as a result of actions by their own Islamist militants or by Islamist militants of other Arab countries.

As if it was not enough for Palestinians of Occupied Territories to undergo violence perpetrated by Israeli forces and settlers, insecurity was also worsened by clashes between different Palestinian factions. The most serious of these clashes, involving the opposed forces of FATAH and those affiliated with HAMAS, resulted in the ousting of FATAH from Gaza in July 2007.

Tensions also ran high in Lebanon between November 2006 and July 2008 during the confrontation between opposition forces led by Hezbollah and those supporting the government. The confrontation, which was originally meant to be largely peaceful, engendered clashes between supporters of each camp, particularly in Beirut in 2007, and escalated to the near occupation of Beirut by the militias of Hezbollah in May 2008.

\section{Identity-based conflict and regional security}

Identity-based conflicts affected regional security in differing degrees. Neighbouring countries have either perceived these conflicts as a threat to their own security or as an opportunity to improve their leverage vis-à-vis their conflictaffected neighbours or both simultaneously. Both Syria and Israel were, for different reasons, so concerned with the possible outcome of the Lebanese civil war that the two intervened by backing certain factions against others. In 1976, Syria wanted to pre-empt a situation that could push it to an unwanted war with Israel. And Israel intervened in order to bar victory of hostile factions who supported Palestinian resistance organisations. Thus, Syria sent troops in 1976 to back conservative Lebanese factions who were about to be defeated by the forces of the Lebanese nationalist movement. Israel on the other hand, launched war in the summer of 1982 in support of the same Lebanese conservative factions. This war brought its army to Beirut, temporarily installed a government that was friendly towards Israel, and forced Palestinian armed factions led by Yassir Arafat to leave Lebanon and seek refuge in Tunisia, far away from Israel's borders.

The Kurdish revolt in Iraq and the Iraqi Kurds' desire for self-governing status were seen by some regional actors as threats and by others as opportunities. The revolt, with its eventually favourable consequences for the Iraqi Kurds, exerted a demonstration effect on Kurds in neighbouring countries and aroused fear among their governments that Kurds might aspire to similar status. Such fear was felt strongly in Turkey, whose government was so opposed to Kurdish national aspirations that it almost threatened to stop such independence by force if ever Iraqi Kurds dared proclaim it. Additionally, the Kurdish region in the north of Iraq was seen by the Turkish military as a threat to Turkey's security, since fighters of the Kurdish Workers Party (PKK) found sympathetic sanctuary among its inhabitants. Turkish troops played havoc with Iraqi sovereignty as they claimed the right of 'hot pursuit' against their compatriots who found refuge there. The Syrian government, which was experiencing a Kurdish problem of its own, used the PKK as a card to play against Turkey, offering assistance and sanctuary to PKK militants. The Turkish government in its turn threatened to launch war on Syria if it continued to back the PKK. Under heavy Turkish pressure, the Syrian government closed PKK camps on its territory. But even after this regional setback, Syrian Kurds again organised in 2007 and 2008 to protest their treatment by Syrian authorities, showing that the rising tide of Kurdish nationalism in the region did not stop at Syria's borders (Gunter 2008; Yildiz 2008).

The conflict in Southern Sudan has affected regional security in neighbouring non-Arab countries such as Ethiopia, Eritrea, Chad and Uganda, as governments of these countries shared borders with Sudan and took opposed positions towards both the Sudanese government and rebels in the South or in Darfur. The Sudanese government in turn backed rebel groups in these countries. Thus, those forces opposing the Sudanese government could find sanctuary in neighbouring countries, while those fighting governments of these neighbouring countries acquired support from the government in Khartoum. This state escalated into periodic clashes between the Sudanese forces and 
neighbouring countries, particularly Ethiopia and Chad, though overall security in the Arab world was not much affected (Jok 2007).

While none of the three major ethnically framed conflicts in the Arab world posed direct threats to international security beyond the region, all aroused interest among the big powers. The brief Lebanese civil war of 1958 brought US forces to Lebanon. The more protracted civil war of 1975-91 brought US troops again, accompanied by detachments of French, Italian and British soldiers following Israel's invasion of the country in June 1982, which led to the departure of Palestinian fighters from Beirut. The Reagan administration sent troops not out of any direct concern for US security but out of worry that the pro-Western Lebanese government might not be able to impose authority over opposing Lebanese militias. Another reason for intervention was to give the impression that the US and Western allies cared for the safety of Palestinian civilians after the tragedy of Sabra and Chatila refugee camps, where 700-800 Palestinians were massacred by Lebanese Christian militias supported by the Israeli army. Maintaining the US and French troop presence in Lebanon did not prove easy, and US marines had to leave Beirut in March 1984 in the wake of a truck explosion in Marines barracks in Beirut that killed 241 US soldiers. A similar incident led to the death of 56 French soldiers who also later withdrew (Kelly 1996).

The attempt by the Iraqi government under Saddam Hussein to crush the Kurdish rebellion was not in itself a threat to US interests. However, the situation in the North of Iraq following the end of the US war of Kuwait in 1991 provided the USA, the UK and France an opportunity to exert further pressure on the Ba'athist regime and to show solidarity with an ally that would prove to be indispensable when the USA decided to invade Iraq later. The three countries imposed a no-fly zone north of latitude 36 in April 1991 in order to dissuade the Iraqi airforce from attacking Kurdish positions. This action enabled the Kurds to enjoy peace in their own region and to exercise de facto self-government, a state that was consolidated with the adoption of an Iraqi constitution that recognised de jure autonomy of the region following US occupation of Iraq in 2003.

\section{Islamist and other political identities as perceived sources of regional and international insecurity}

Conflicts of identity stemming from opposed views on religion in politics were seen as serious threats to national, regional and international security and such threats were of concern to almost all Arab countries. Those that did not experience armed attacks by militant Islamists were wary that their activities in neighbouring countries might have a contagious effect within their own borders. Interestingly, those countries that banned mainstream political organisation were the ones that experienced the worst domestic political violence between security forces and militant Islamist factions (e.g. Saudi Arabia). It is true that those countries that tolerated mainstream Islamist movements, such as Morocco, Jordan and Yemen, were not completely immune to violent acts by militant Islamists. But the threat in these countries was of a much more limited and of intermittent character compared with the protracted strife in countries banning mainstream movements (Al-Sayyid 2003).

Armed militant Islamists were soon viewed by Arab governments to be a regional and even international threat. The regional character of this threat was manifested in what was believed to be coordination of activities of these groups in several Arab countries. Those who carried out the attack on the Ka'ba in 1979 came from different Muslim countries. The young Egyptians who tried to assassinate President Hosny Mubarak in Ethiopia in 1995 came from Sudan, where they had support from fellow Islamists in ruling circles. In response, Arab governments started to coordinate activities to combat militant Islamism, and their ministers of internal affairs, in charge of domestic security would gather annually to discuss ways of confronting this common 'danger'.

This danger had acquired an international character, long before the events of 11 September 2001. Osama Bin Laden had established his World Islamic Front for Jihad against Jews and Crusaders in 1998, three years before the September 2001 attacks. His plan was to fight those he considered enemies of Islam in all parts of the world. Militants associated with this organisation, which came to be known later as the Qa'eda, struck against US interests in Africa and South Arabia. Bin Laden was joined 
by young Islamists from many countries, including both Arab and non-Arab parts of the world. The worldwide response was not limited to the so-called 'war on terrorism' launched by US president George W. Bush, but it brought together a vast network of countries, in the fight against what they considered to be Islamic militancy. These countries included the Russian Federation, China, India, the Philippines, the UK, France and Spain. A larger number of countries sent troops to Iraq in response to calls by Bush, who claimed that his military occupation of Iraq was an attempt to crush a regime that was allegedly supportive of 'Islamic terrorists', a claim that was found later to be entirely unfounded. The UN was drawn to this effort as its participation was required in order to trace sources of funding concerning those associated with Bin Laden's organisation in the hope of denying them such resources.

Yet commitment to a militant interpretation of Islam was not the only instance of a political identity fuelling violent conflicts in Arab countries. Espousal of divergent political ideals could lead to similar consequences. Palestinians favouring a vision of their future alongside Israel have engaged in fighting other Palestinians who believe that salvation lies with the annihilation of Israel as a country of Jews that established itself on territory these Palestinians consider exclusively as their own. But although commitment to these divergent ideals was a source of tension between FATAH and HAMAS, the bloody conflict between the two organisations in the summer of 2007 was not caused by philosophical differences, so much as by a naked struggle over power. FATAH leaders did not easily accept their electoral defeat by HAMAS in an election that was considered by most observers to have been conducted fairly and freely. The same observation applies to the tense situation in Lebanon between November 2006 and July 2008 that threatened to engulf Lebanon in a new civil war and placed Christians and Muslims in the two adversary camps. It would be difficult to analyse this dispute solely in terms of identity, although it was perceived in such terms by many Shi'is and Sunnis in Lebanon and outside it, particularly in Sunni majority countries including Saudi Arabia, Egypt and Jordan.

External support has also been crucial in sustaining rebellions. Rebels in Southern Sudan and Darfur enjoyed support from other African countries, the USA and Israel. The Kurds in Iraq had support from the USA, West European governments and Israel. The Conservative factions in the Lebanese civil war also had the same sources of support, with Israel intervening militarily to pre-empt victory of the allies of the Palestinian organisations and to drive these organisations away from Lebanon. External support was not lacking for the two Palestinian factions either. In the case of Algeria, Islamist militants could also count on support from Islamist organisations in other countries, although their extensive networks inside Algeria spared them the need for substantial external backing.

\section{Are there ways out of identity-based conflict?}

A good starting point is to ask why identityframed conflicts broke out in countries like Sudan, Iraq, Lebanon, Algeria and Palestine, but not in countries like Morocco, Tunisia and Jordan, at least not to the same degree of duration, scope and impact on human security.

Lack of respect for the adversary, to use a notion articulated by Geertz (1994), was common in all these situations, but one can find signs of this lack of respect for the 'other' in countries that did not undergo similar conflicts. So why did historically aggrieved or subordinated groups revolt in these countries but not in the others?

One line of explanation is that improvements in the economic and social conditions of subordinate groups have seemed possible in the second set of countries. Collective consciousness along primordial or ideological lines has not been as strong. And the different communities have not experienced markers of identity as an obstacle to upward mobility.

Such improvements have not occurred in most countries experiencing violent conflict. The cases of Sudan, Iraq and Lebanon suggest that political tensions and violence have arisen when legitimate rights to equal citizenship were denied, starting with the right to declare and acquire recognition for ethnic and other identities. For instance, leaders in Sudan in 1984 and Iraq in 1975 soon reneged on their commitments to respect terms of settlement of civil disputes. In the case of Lebanon, Christian parties saw, in the reform demands of the 
Lebanese Nationalist Movement, an end to the special position of Christians in the country and were ready to use force to quell any attempt to change the National Pact of 1943, which institutionalised their privileges.

In sum it is important to respect the cultural rights of those perceived to be in minority situations, and to respond flexibly to their demands for autonomy ranging from administrative decentralisation to a federal arrangement. It has taken both the Sudanese and the Iraqi governments a long time to begin to negotiate with and recognise the rights of rebel minorities, in Iraq's case only in the aftermath of very destructive and traumatic external intervention - and in neither case has such reconciliation been fully put into practice. The delay has cost these countries protracted and bloody civil wars in which hundreds of thousands of people have either lost their lives or suffered uprooting from their native lands.

Agreements to share power and wealth as in Sudan, Iraq and Lebanon, have also played a role in the restoration of peace. In Algeria and the Palestinian Territories, the conflict has continued at least in part because of the absence of such

\section{Notes}

1 Egypt and Algeria offer the best support for this observation. Militant Islamists were particularly active in poor districts of major towns and in poor areas of the country. Moroccan Islamists who perpetrated the suicide bombings in Casablanca in April 2007 originated also from poor districts in the city. Mainstream movements attracted support

\section{References}

Al-Rasheed, Madawi (2007) Contesting the Saudi State: Islamic Voices from a New Generation, Cambridge: Cambridge University Press Al-Rasheed, Madawi (1998) 'The Shi'a of Saudi Arabia: A Minority in Search of Cultural Authenticity', British Journal of Middle Eastern Studies 25.1: 121-38

Al-Sayyid, Mustapha Kamel (2003) The Other Face of the Islamist Movement, Washington DC: Carnegie Endowment for International Peace, Democracy and Rule of Law Project, Global Policy Program Working Paper 33, January agreement. The violence diminished (but did not fully end) in Algeria after 1999 when an attempt at reconciliation was made, but also when it became clear that rebel groups could not win the struggle against the government militarily. The drive to take up arms against the government in the name of Islam only began to run out of steam when national reconciliation allowed some parties with Islamist credentials to be part of the political process and in fact to share in the government. ${ }^{2}$

Yet it would be simplistic to reduce all intergroup tensions to socioeconomic causes and differential access to political power. Identity feelings of primordial, ideological or political types are deliberately provoked and fed by activists who hope to build a political capital out of the manipulation of such feelings. They can also flow from deep-rooted beliefs that generate negative images of the 'other'. However, neither the manipulation of primordial loyalties nor the survival of outdated images of the 'other' would suffice to cause much inter-group tension or conflict unless they coincided with differential access to power, wealth and respect along identity lines. Such inequalities must be addressed in order to create sustainable peace in the Arab world.

usually among people of middle class, and particularly those of middle-class professional groups.

2 The Movement of Society for Peace took part in presidential elections and parliamentary elections and was part of a coalition government after 2004. It is called HAMAS in Arabic and is close to the international movement of Muslim Brothers.

Connor, Walker (1994) Ethnonationalism: The Quest for Understanding, Princeton: Princeton University Press

Corm, Georges (2005) Loubnan al-mo'asir, Tarikh wa mujtama [Contemporary Lebanon: History and Society], Beirut: Al-Maktabah Al-Sharqiyyah

Geertz, Clifford (1994) Primordial Loyalties and Standing Entities: Anthropological Reflections on Politics of Identity, Budapest: Collegiums Budapest/Institute for Advanced Study, Public Lecture No. 7, April

Gellner, Ernest and Waterbury, John (1977) Patron and Client in Mediterranean Societies, 
London: Duckworth; Hanover: Center for Mediterranean Societies of the American Universities Field Staff

Ghareeb, Edmund (2003) 'The Kurdish Issue', in Shams C. Enati (ed.), Iraq, Its History, People and Politics, New York: Humanity Books

Gunter, Michael M. (2008) The Kurds Ascending:

The Evolving Solution to the Kurdish Problem in Iraq and Turkey, New York: Palgrave Macmillan Ibrahim, Saad Eddin (1998) 'Ethnic Conflict and State-Building in the Arab World', International Social Science Journal 50: 156

Jok Madut Jok (2007) Sudan: Race, Religion and Violence, Oxford: One World

Kelly, John (1996) 'Lebanon 1982-1984', in Jeremy R. Azrael and Emil A. Payin (eds), US and Russian Policy Making with Respect to the Use of Force, Washington DC: Rand
Luckham, Robin; Moncrieffe, Joy and Harris, Colette (2006) Understanding the Routes In and Out of Political Violence: An Assessment of the Linkages Between Identity Politics, Exclusion, Inequality and Political Violence in EMAD Countries, Final Report to DFID, London

Seale, Patrick (1988) Asad of Syria: The Struggle for the Middle East, with the assistance of Maureen McConville, London: Tauris

UNDP (2009 forthcoming) Human Security in the Arab World, New York: UNDP, ch. 2-3

Yildiz, Kerim (2008) The Kurds in Iraq: Past, Present and Future, London, Ann Arbor, MI: Pluto Press in association with Kurdish Human Rights Project 